\title{
Molecular survey of Anaplasma and Ehrlichia species in cattle from Karaman of Turkey, including a novel tandem report of Anaplasma marginale msp1a gene
}

\author{
Mehmet Fatih AYDIN ${ }^{1 a \bowtie}$, Sezayi ÖZÜBEK ${ }^{2 b}$, Münir AKTAŞ ${ }^{2 c}$ \\ ${ }^{1}$ Karamanoğlu Mehmetbey University, Faculty of Health Sciences, Karaman; ${ }^{2}$ Firat University, Faculty of Veterinary Medicine, \\ Department of Parasitology, Elazı̆ $\breve{g}$, Turkey.
} aORCID: 0000-0002-8325-4887, bORCID: 0000-0001-5231-2258, ' ${ }^{\mathrm{O}}$ ORCID: 0000-0002-3188-8757

\author{
${ }^{\otimes}$ Corresponding author: veterinermfa@gmail.com \\ Received date: 31.08.2018 - Accepted date: 06.05.2019
}

\begin{abstract}
Tick-borne pathogens cause serious health problems and loss of productivity in domesticated and wild animals. A molecular study was performed to detect the frequency of infection with Anaplasma/Ehrlichia (A/E) in cattle from Karaman province of Turkey. Venous blood samples were taken from 150 apparently healthy cattle in 2016. After amplification the hypervariable V1 region of the 16S rRNA gene of A/E species, a reverse line blot (RLB) assay was performed using species-specific probes. Since some samples gave signal only to A/E catch-all probe, the samples analyzed in terms of major surface proteins (MSPs) of Anaplasma marginale. Genetic diversity and tandem repeat analysis were made for mspl $\alpha$ gene sequences of A. marginale. Anaplasma-like bodies were detected in four $(2.66 \%)$ animals via microscopic examination. Anaplasma centrale was detected in eight (5.33\%) animals via RLB. When the samples were examined in terms of A. marginale msp1a gene with semi-nested PCR, a total of nine (6.00\%) animals [six of them (4.00\%) were positive for A. centrale with RLB] were found to be infected with A. marginale. In addition, the sequences of MSP1a amplicons revealed one new tandem repeat (Tr70). According to these results, it was determined that A. marginale and A. centrale were found in cattle in Karaman province and this study provided the first evidence of genetic diversity of A. marginale with one new tandem repeat in cattle in the region.
\end{abstract}

Keywords: A. centrale, A. marginale, cattle, Karaman, tandem repeat.

\section{Anaplasma marginale msp1a geninin yeni bir tandem raporunu da içeren, Türkiye'nin Karaman yöresindeki sığırlarda Anaplasma ve Ehrlichia türlerinin moleküler araştırması}

Özet: Kene kaynaklı patojenler evcil ve yabani hayvanlarda ciddi sağlık problemlerine ve verim kaybına neden olur. Karaman ilindeki sığırlarda Anaplasma / Ehrlichia (A/E) ile enfeksiyon sıklığını saptamak için moleküler bir çalışma yapıldı. Venöz kan numuneleri görünüşte sağlıklı olan 150 sığırdan 2016 yılında alınmıştır. A/E türlerinin 16S rRNA geninin değişken V1 bölgesi amplifiye edildikten sonra tür spesifik problar kullanılarak reverse line blot (RLB) deneyi gerçekleştirilmiştir. Bazı örnekler sadece A/E probuna sinyal verdiğinden, örnekler Anaplasma marginale'nin major surface proteinleri (MSPs) açısından analiz edilmiştir. A. marginale'nin msp1 $\alpha$ gen dizileri için genetik çeşitlilik ve tandem tekrar analizi yapıldı. Mikroskobik inceleme ile dört (\%2.66) hayvanda Anaplasma benzeri cisimler tespit edildi. Anaplasma centrale RLB ile sekiz (\%5.33) hayvanda tespit edildi. Örnekler seminested PZR ile A. marginale mspla geni açısından incelediğinde, toplam dokuz (\%6.00) hayvanın [6's1 (\%4.00) RLB ile A. centrale açısından pozitif olan] A. marginale ile enfekte olduğu bulunmuştur. Ek olarak, MSP1a amplikonlarının dizileri bir tane yeni tandem tekrarı (Tr70) ortaya çıkardı. Bu sonuçlara göre Karaman ilindeki sığırlarda A. marginale ve A. centrale'nin bulunduğu tespit edilmiş ve bu çalışma bölgedeki sığırlarda bir yeni tandem tekrarı ile $A$. marginale' nin genetik çeşitliliğinin ilk kanıtını sağlamıştır.

Anahtar sözcükler: A. centrale, A. marginale, Karaman, sı̆̆ır, tandem tekrarı.

\section{Introduction}

Tick-borne diseases (TBDs) poses a great impact for animal and human health in tropical and subtropical climatic regions including Turkey. Turkey has a grand potential for animal breeding and livestock population comprises 14 million cattle, 29 million sheep and 9 million goats. Since TBDs (e.g. theileriosis, babesiosis and anaplasmosis) cause management problems due to significant economic losses, accepted as pre-eminent health trouble worldwide (21) and it is important that a real diagnosis and an effective treatment should be performed. 
Anaplasma spp. are significant tick-borne bacteria because of medical and veterinary significance (16). Most common agent for cattle anaplasmosis is Anaplasma marginale. Biological transmission of A. marginale is associated with ticks mainly genera of Rhipicephalus and Dermacentor (22). Anaplasma marginale is highly pathogenic for cattle and the major signs are anemia, fever, icterus, weight loss and death (6). Until today, a large number of tandem repeats and genotypes have been identified based on the variability of tandem amino acid sequences in the mspla gene region of A. marginale (13). More than two hundred and fifty tandem repeats have been reported in various parts of the world (11). It has been reported new tandem repeats in China, Turkey and Russia with recent studies $(4,18,28)$.

Bovine anaplasmosis can be diagnosed on the basis of clinical symptoms and microscopic examination of Giemsa-stained blood smears $(20,29)$. It is adequate for the detection of acute infection, but not possible for detection of carrier animals. Serologic tests have been employed in diagnosing subclinical infections in epidemiological studies (9), but cross-reactions between species and false-negative results are potential restrictions. It is possible to eliminate these disadvantages with molecular techniques provide improved sensitivity and specificity than microscopy and serology. In addition to these, veterinary practitioners have a limited laboratory facility in field conditions, also early treatment is very important for TBDs.

Although clinical and subclinical infections have been reported data concerning genetic variants of these pathogens is scarce. This study provides information about the distribution and frequency of Anaplasma/Ehrlichia (A/E) species in cattle from Karaman province of Turkey with a novel genetic variant of A. marginale.

\section{Materials and Methods}

Study area and sample collection: This study was carried out in Karaman province $\left(37^{\circ} 11^{\prime} \mathrm{N}, 33^{\circ} 15^{\prime} \mathrm{E}\right)$ located in the south of the Central Anatolia Region of Turkey (Figure 1) and it was conducted in compliance with the regulation issued by Karamanoğlu Mehmetbey University Animal Experiments Local Ethics Committee (2016/01). Sampling was performed in 2016. The Karaman province is 1033 meters above sea level and has an area of $8869 \mathrm{~km}^{2}$. It has a continental climate with hot summers and cold winters. The mean annual rainfall and temperature are $336.3 \mathrm{~kg} / \mathrm{m}^{2}$ and $12{ }^{\circ} \mathrm{C}$, respectively. Agriculture/animal husbandry and related industrial sector activities have an important place in the Karaman economy. One hundred fifty clinically healthy cattle from 21 different locations throughout Karaman were examined for clinical findings of anaplasmosis (body temperature, mucous membrane color and size of subcutaneous lymph nodes) between April and September 2016. Age, gender and breed of animals were saved. Five ml of blood sample were taken from the vena jugularis into tubes containing $\mathrm{K}_{3}$ EDTA-anticoagulant from each animal.

Preparation of blood smears and DNA isolation: Thin blood smears prepared from animals were fixed with absolute methanol for five minutes and stained with $5 \%$ Giemsa stain for 30 minutes. The slides were rinsed with water, and after drying in the air they were screened under oil immersion $(\times 100$ magnification $)$ for the presence of Anaplasma-like bodies. At least 100 microscope fields have been examined and even if an agent has been found, the sample has been evaluated as positive.

Blood samples were defrosted at room temperature and vortexed for 15 seconds to homogenize. A commercial kit (QIAamp DNA Mini Kit, 51306) was used to isolate total genomic DNA. The DNA extraction was performed as described in the kit protocol using $200 \mu \mathrm{l}$ blood sample. Genomic DNAs were stored at $-20{ }^{\circ} \mathrm{C}$ until used as a template in the PCR.

Polymerase chain reaction and reverse line blot hybridization assay: Nested PCR was performed using two universal primers. EC9 (5'-TACCTTGTTACG ACTT-3') and EC12A (5'-TGATCCTGGCTCAGAACG AACG-3') which amplify $1450 \mathrm{bp}$ fragment in the hypervariable V1 region of the $16 \mathrm{~S}$ rRNA gene of A/E was used for the first amplification (12). For the second amplification, one $\mu \mathrm{l}$ of first round PCR products were used as a template DNA. To amplify 492-498 bp in the hypervariable $\mathrm{V} 1$ region in $16 \mathrm{~S}$ rRNA gene of $\mathrm{A} / \mathrm{E}$, 16S8FE (5'-GGAATTCAGAGTTGGATCMTGGYT CAG-3') and BGA1B-new (Biotin-5'- CGGGATCCC GAGTTTGCCGGGACTTYTTCT-3') primers (8, 26) were used. To reduce non-specific amplification, a touchdown program was performed. DNA from positive control and distilled water were used. The PCR was performed in a final volume of $25 \mu \mathrm{l}$, containing PCR buffer [750 mM Tris- $\mathrm{HCl}(\mathrm{pH} 8.8), 200 \mathrm{mM}\left(\mathrm{NH}_{4}\right)_{2} \mathrm{SO}_{4}$, $0.1 \%$ Tween 20], $5 \mathrm{mM} \mathrm{MgCl} 2,125 \mu \mathrm{M}$ deoxynucleotide triphosphates, 1.25 U Taq DNA polymerase, forward and reverse primers $(10 \mathrm{pmol} / \mu \mathrm{l})$, and template DNA. Five microliters of PCR product were visualized using UV transillumination in a $1.6 \%$ agarose gel stained with ethidium bromide and the remaining amplicons were stored for RLB until hybridization. Probes containing Nterminal $\mathrm{N}$-(trifluoracetamidohexyl-cyanoethyl,N,Ndiisopropylphosphoramidite [TFA])-C6 amino linker were synthesized by "Midland Certified Reagent Company, Inc." and used with a range of 200-900 pmol/150 $\mu$ l concentration (Table 1). Preparation of biodyne $\mathrm{C}$ membrane, hybridization and rinsing were as previously described (7). Black spots in rows were evaluated by ChemiDoc ${ }^{\text {TM }}$ MP System (Bio-Rad, UK) can make chemiluminescence detection. 
Table 1. Sequences of oligonucleotides used in RLB.

Tablo 1. RLB'de kullanılan oligonükleotidlerin dizilimleri.

\begin{tabular}{llc}
\hline Oligonucleotide probe & Sequence (5'-3) & Reference \\
\hline Anaplasma/Ehrlichia & AmMC6-TTATCGCTATTAGATGAGCC & 26 \\
EhrlichialAnaplasma catch-all & AmMC6-GGGGGAAAGATTTATCGCTA & 8 \\
Anaplasma marginale & AmMC6-GACCGTATACGCAGCTTG & 8 \\
Anaplasma centrale & AmMC6-TCGAACGGACCATACGC & 8 \\
Anaplasma bovis & AmMC6-GTAGCTTGCTATGAGAACA & 8 \\
Ehtlichia sp. strain Omatjenne & AmMC6-CGGGTTTTTATCATAGCTTGC & 8 \\
Anaplasma phagocytophilum 1 & AmMC6-TTGCTATAAAGAATAATTAGTGG & 26 \\
Anaplasma phagocytophilum 3 & AmMC6-TTGCTATGAAGAATAATTAGTGG & 26 \\
Anaplasma phagocytophilum 5 & AmMC6-TTGCTATAAAGAATAGTTAGTGG & 26 \\
Anaplasma phagocytophilum 7 & AmMC6-TTGCTATAGAGAATAGTTAGTGG & 26 \\
Anaplasma phagocytophilum A-HGE & AmMC6-GCTATAAAGAATAGTTAGTGG & 26 \\
Anaplasma phagocytophilum A-D-HGE & AmMC6-GCTATGAAGAATAGTTAGTG & 26 \\
\hline
\end{tabular}

Anaplasma marginale specific semi-nested PCR: A semi-nested PCR protocol for msp $1 \alpha$ gene was conducted as described by Lew et al. (23). The primers 1733F (5'TGTGCTTATGGCAGACATTTCC-3') and 3134R (5'TCACGGTCAAAACCTTTGCTTACC-3') were used in the first PCR, and the primer pair 1733F and 2957R (5'AAACCTTGTAGCCCCAACTTATCC-3') was used in the second reaction. For the second PCR amplification, one $\mu \mathrm{l}$ of the first product was used as a template. Amplification was carried out under conditions previously reported. PCR amplicons were separated by electrophoresis on $1.6 \%$ agarose gel (40 min, $100 \mathrm{~V}$ ), stained with ethidium bromide, and visualized under ultraviolet light. Anaplasma marginale control DNA was previously isolated from a cow (GenBank accession no. GU201518).

DNA sequencing, MSPla microsatellite and tandem repeat analysis: Five amplified fragments containing variable regions of $A$. marginale mspl $\alpha$ gene were purified from the agarose gel using a commercial PCR Clean up System (MinElute Gel Extraction Kit, 28604) and directly sequenced. The MAFFT (https://mafft.cbrc.jp/) and Emboss Transeq (https://www.ebi.ac.uk/Tools/st/emboss_transeq/) programs were used to conduct multiple alignments and translate nucleotide to an amino acid of MSP1a sequences respectively. Sequencing results submitted to GenBank after comparing with other sequences available in the NCB database (http://www.ncbi.nlm.nih.gov/nuccore). The isolates were identified according to the nomenclature as previously reported $(10,15)$. The nature of the microsatellite structure was GTAGG (G/A TTT) m (GT) nT ATG (17). Calculation of the SD-ATG distance was performed as $(4 \times \mathrm{m})+(2 \times \mathrm{n})+1$. The microsatellite analysis was conducted using the RepeatAnalyzer (11), and the nature of tandem repeats was indicated as previously proposed (15).

\section{Results}

Microscopic examination of blood smears: Anaplasma-like bodies were detected in four (2.66\%) Giemsa-stained blood smears. All of the animals evaluated as positive in the microscopic examination are from Karaman center.

Detection of Anaplasma spp. by RLB: One hundred and fifty blood samples were screened for the presence of bovine $\mathrm{A} / \mathrm{E}$ species. According to RLB results, eight out of 150 cattle $(5.33 \%)$ were found to be infected with $A$. centrale. Three samples gave positive signals to $\mathrm{A} / \mathrm{E}$ catch-all probes and no species-specific probe signal received. No animals were infected with Ehrlichia spp. (Table 2).

Anaplasma marginale specific semi-nested PCR amplification: Nine samples $(6.00 \%)$ [three of them gave positive signals to $\mathrm{A} / \mathrm{E}$ catch-all probes and eight of them were found to be positive in terms of $A$. centrale via RLB] were positive in terms of $A$. marginale according to the semi-nested PCR with primers (1733F and 3134R - 1733F and 2957R) amplifying the mspla gene.

DNA sequencing, MSPla microsatellite and tandem repeat analysis: Five $A$. marginale positive samples were sent to sequence analysis and obtained sequences of msp1 $\alpha$ gene were submitted to GenBank (accession numbers MG983513 to MG983517). Tandem repeat sequences and structure of the mspl $\alpha$ gene were analyzed to discover differences. Three different types of MSP1a tandem repeats with 23 to 29 amino acids for $A$. marginale strains were identified (Figure 2a). The MSP1a microsatellite analysis revealed that $\mathrm{E}$ genotype was detected in the analyzed sequences and microsatellite sequences produced SD-ATG distances 23 nucleotide. One new microsatellite structure designated as $\operatorname{Tr} 70[(\mathrm{~m}=$ $2, \mathrm{n}=7$, SD-ATG distance $=23$ ), (ADSSSAGGVLSQS GQASTSSQLG)] was described (Figure 2b). It was determined that $A$. marginale strains had 2 and 4 MSP1a repeat sequences in the studied area (Figure $2 c$ ). 
Table 2. Distribution of Anaplasma species detected by microscopy, PCR and RLB.

Tablo 2. Mikroskop, PZR ve RLB ile tesbit edilen Anaplasma türlerinin dağılımı.

\begin{tabular}{|c|c|c|c|c|c|c|c|}
\hline \multirow[b]{2}{*}{ Province } & \multirow[b]{2}{*}{$\mathbf{n}$} & \multicolumn{3}{|c|}{ Test } & \multicolumn{3}{|c|}{ Overall results } \\
\hline & & $\begin{array}{c}\text { Microscopy } \\
\text { Anaplasma spp. }\end{array}$ & $\begin{array}{c}\text { RLB } \\
\text { A. centrale }\end{array}$ & $\begin{array}{c}\text { A. marginale } \mathrm{nPCR} \\
\text { A. marginale }\end{array}$ & $\begin{array}{c}\text { A. } \\
\text { marginale }\end{array}$ & $\begin{array}{c}\text { A. } \\
\text { centrale }\end{array}$ & $\begin{array}{l}\text { A. marginale } \\
+ \text { A. centrale }\end{array}$ \\
\hline Karaman center & 42 & 4 & 2 & 3 & 2 & 1 & 1 \\
\hline Kazımkarabekir & 16 & - & 3 & 3 & - & - & 3 \\
\hline Ayranc1 & 56 & - & 1 & 2 & 1 & - & 1 \\
\hline Ermenek & 36 & - & 2 & 1 & - & 1 & 1 \\
\hline Total & 150 & $\begin{array}{c}4 \\
(2.66 \%)\end{array}$ & $\begin{array}{c}8 \\
(5.33 \%)\end{array}$ & $\begin{array}{c}9 \\
(6.00 \%)\end{array}$ & $\begin{array}{c}3 \\
(2.00 \%)\end{array}$ & $\begin{array}{c}2 \\
(1.33 \%)\end{array}$ & $\begin{array}{c}6 \\
(4.00 \%)\end{array}$ \\
\hline
\end{tabular}

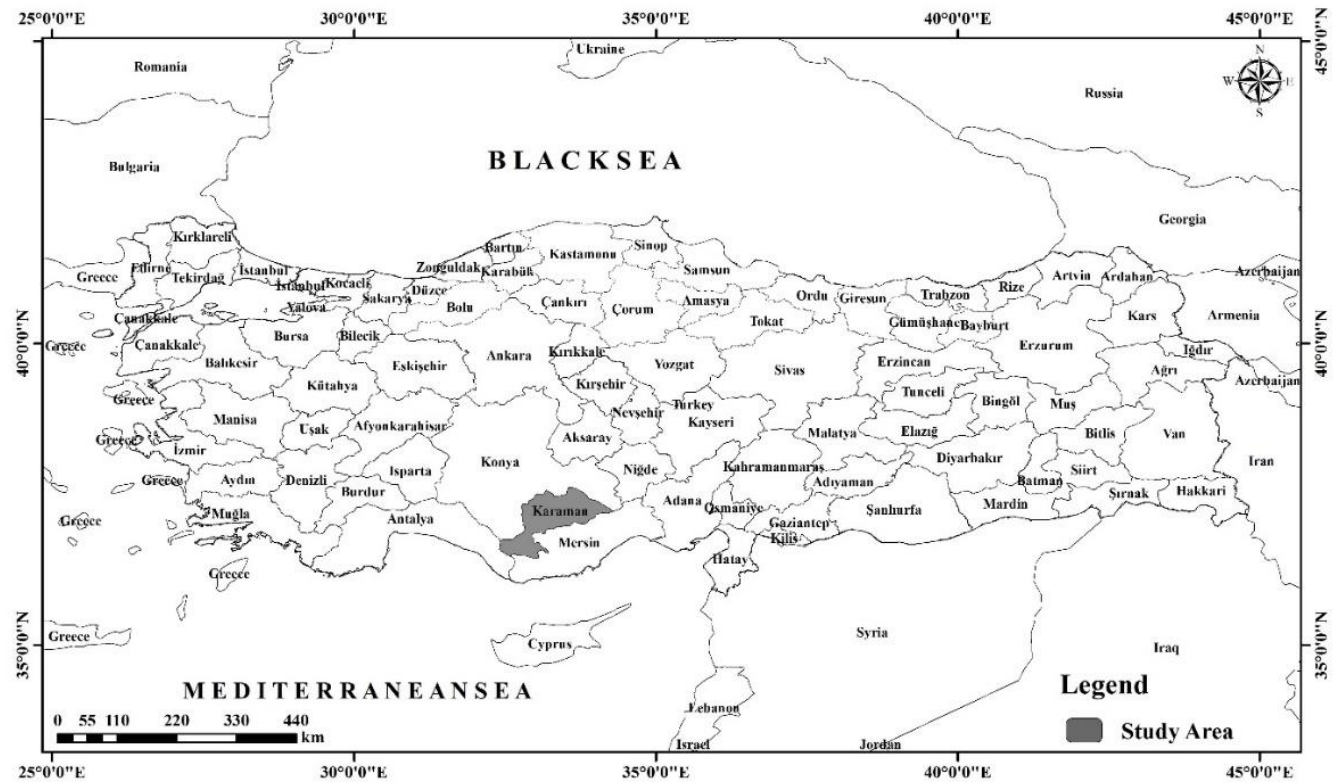

Figure 1. Turkey map showing the study area.

Şekil 1. Çalışma alanını gösteren Türkiye haritası.

a)

\begin{tabular}{ccc}
\hline Repeat form & Encoded sequence & Number of amino acid \\
\hline $\operatorname{Tr} 1$ & ADSSSAGDQQQESSVLSQSDQASTSSQLG & 29 \\
Tr70* & ADSSSAG-----GVLSQSGQASTSSQLG & 23 \\
Is1, 73 & TDSSSAGDQQQESGVSSQSGQASTSSQLG & 29 \\
\hline
\end{tabular}

b)

\begin{tabular}{cccccc}
\hline Isolates & Accesion number & Genotype & $\mathrm{m}$ & $\mathrm{n}$ & SD-ATG distance (nucleotide) \\
\hline Kr3 & MG983513 & $\mathrm{E}$ & 2 & 7 & 23 \\
Kr7 & MG983514 & $\mathrm{E}$ & 2 & 7 & 23 \\
Kr37 & MG983515 & $\mathrm{E}$ & 2 & 7 & 23 \\
Kr58 & MG983516 & $\mathrm{E}$ & 2 & 7 & 23 \\
Kr78 & MG983517 & $\mathrm{E}$ & 2 & 7 & 23 \\
\hline
\end{tabular}

c)

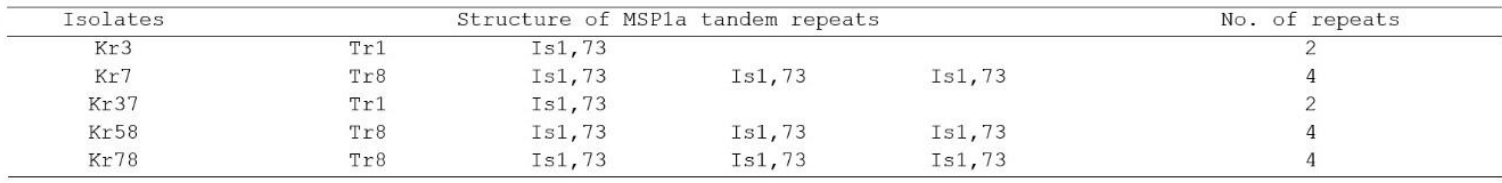

Figure 2a. New repeat forms of Anaplasma marginale MSP1a ( $\left.\operatorname{Tr} 70^{*}\right)$ identified. The one letter amino acid code was used to depict the differences found in MSP1a repeats. 2b. The mspl $\alpha$ microsatellite and tandem repeat sequences in Anaplasma marginale isolates. The microsatellite (sequence in bold) was located between the Shine-Dalgarno and the translation initiation codon (ATG) with the structure: GTAGG (G/ATTT)m (GT)n T ATG. 2c. The structure of the MSP1a repeat regions, according to the nomenclature previously proposed $(11,15)$.

Şekil 2a. Anaplasma marginale MSP1a'nın (Tr70*) yeni tekrar formları belirlenmiştir. MSP1a tekrarlarında bulunan farklılıkları tasvir etmek için bir harfli amino asit kodu kullanılmıştır. 2b. Anaplasma marginale izolatlarında mspl $\alpha$ mikrosatellit ve tandem tekrar dizileri. Mikrosatellit (koyu sıralı) Shine-Dalgarno ile translasyon başlatma kodonu (ATG) arasında, yapı ile birlikte: GTAGG (G / ATTT)m (GT)n T ATG. 2c. MSP1a'nın tekrarlanan bölgelerinin yapısı, daha önce önerilen terminolojiye göre $(11,15)$. 


\section{Discussion and Conclusion}

In recent years, studies related to ticks and TBDs has increased and TBDs cause a major health problem and loss of production in cattle in Turkey. Anaplasma phagocytophilum, A. marginale, A. centrale, A. bovis and Ehrlichia sp. strain Omatjenne have been reported in cattle from Turkey (1-3, 5, 19). Among Anaplasma species, A. marginale is the most pathogenic species causing infections in cattle and it is known to cause clinical infections resulting in death (22), while A. centrale causes milder infections (25).

Major surface protein 1a, an important protein to determine genetic diversity of A. marginale strains, interacts with the vertebrate and invertebrate host cells of the bacterium (14). Cattle movement is a prominent factor for the MSP1a genetic diversity in A. marginale worldwide $(15,27)$. Supported by the finding of one MSP1a genotype in Australia, where cattle entry is limited (23). To date, eleven different genotypes (A-K) of $A$. marginale mspla gene in worldwide were described (10, 17). In this study, we present the genotypic variant $E$ of $A$. marginale based on mspla gene sequences. $\mathrm{C}, \mathrm{E}$, and $\mathrm{G}$ genotypes were previously reported in dairy cattle from Turkey (4). More than two hundred fifty A. marginale tandem repeats have been reported in various parts of the world $(4,13,15,18,28)$. In studies on A. marginale msp1a gene conducted in China and Turkey, 21 and 3 new tandem repeats have been reported respectively. A computer program is prepared to prevent the confusion in tandem repeats (11). Tr1, Tr2, Tr3, 73, 74 and 76 tandem repeats have been reported in dairy cattle in Turkey (4). The one tandem repeat designated as " $T r 70$ " in this study were not previously reported anywhere (11). Also, " $\operatorname{Tr} 1$ " and " 73 " tandem repeats were reported with this present study.

The length of the microsatellite is related to the expression of the mspla gene and affects the transmission of A. marginale and its infection (17). In this study, SDATG distances of 23 nucleotides is a higher expression level. This finding suggests a big capacity for infection and transmission of the A. marginale strains.

Studies conducted with RLB do not result in species level from time to time due to different genotypes among species. In a study conducted on Theileria equi, the sample was not signaled at the species level when signaling against catch-all probe due to different genotypes (24). Similarly, in this study, no signal was detected at the species level when three samples were signaled for A/E catch-all probe. As a result, msp1a gene of A. marginale was amplified and catch-all samples were confirmed as $A$. marginale.

In conclusion, the presence and distribution of $\mathrm{A} / \mathrm{E}$ infections in cattle in Karaman province were investigated using microscopy, PZR and RLB methods in this study.
Anaplasma marginale and A. centrale were detected in cattle. Three different types of MSP1a tandem repeats with one new microsatellite structures designated as $\operatorname{Tr} 70$ for A. marginale strains were identified. It is important to remember that there can be different genotypes and strains of A. marginale when $\mathrm{A} / \mathrm{E}$ catch-all signal is received in similar studies. It is also expected that the diversity of msp1a genotypes can increase related to animal movements and animal imports from abroad.

\section{Acknowledgement}

This work was supported financially by a grant (41M-16) from the Commission of Scientific Research Projects, Karamanoğlu Mehmetbey University.

\section{References}

1. Aktas M, Altay K, Dumanli N, et al. (2009): Molecular detection and identification of Ehrlichia and Anaplasma species in ixodid ticks. Parasitol Res, 104, 1243-1248.

2. Aktas M, Altay K, Dumanli N (2011): Molecular detection and identification of Anaplasma and Ehrlichia species in cattle from Turkey. Ticks Tick-Borne Dis, 2, 62-65.

3. Aktas M, Altay K, Ozubek S, et al. (2012): A survey of ixodid ticks feeding on cattle and prevalence of tick-borne pathogens in the Black Sea Region of Turkey. Vet Parasitol, 187, 567-571.

4. Aktas M, Ozubek S (2017): Outbreak of anaplasmosis associated with novel genetic variants of Anaplasma marginale in a dairy cattle. Comp Immunol Microbiol Infect Dis, 54, 20-26.

5. Aktas M, Vatansever Z, Altay K, et al. (2010): Molecular evidence for Anaplasma phagocytophilum in Ixodes ricinus from Turkey. Trans R Soc Trop Med Hyg, 104, 10-15.

6. Aubry P, Geale DW (2011): A Review of Bovine Anaplasmosis. Transbound Emerg Dis, 58, 1-30.

7. Aydin MF, Aktas M, Dumanli N (2013): Molecular identification of Theileria and Babesia in sheep and goats in the Black Sea Region in Turkey. Parasitol Res, 112, 2817 2824.

8. Bekker CP, de Vos S, Taoufik A, et al. (2002): Simultaneus detection of Anaplasma and Ehrlichia species in ruminants and detection of Ehrlichia ruminantum in Amblyomma variegatum ticks by reverse line blot hybridization. Vet Microbiol, 89, 223-238.

9. Birdane FM, Sevinc F, Derinbay O (2006): Anaplasma marginale infections in dairy cattle: clinical disease with high seroprevalence. Bull Vet Inst Pulawy, 50, 467-470.

10. Cabezas-Cruz A, Passos LMF, Lis K, et al. (2013): Functional and immunological relevance of Anaplasma marginale major surface protein 1 a sequence and structural analysis. PLoS ONE, 8:e65243.

11. Catanese HN, Brayton KA, Gebremedhin AH (2016): Repeat Analyzer: a tool for analysing and managing shortsequence repeat data. BMC Genomics, 17, 422.

12. Chen SM, Dumler JS, Bakken JS, et al. (1994): Identification of a granulocytotropic Ehrlichia species as the etiologic agent of human disease. J Clin Microbiol, 32, 589-595. 
13. De la Fuente J, Garcia-Garcia JC, Blouin EF, et al. (2001a): Evolution and function of tandem repeats in the major surface protein la of the ehrlichial pathogen Anaplasma marginale. Anim Health Res Rev, 2, 163-173.

14. De la Fuente J, Garcia-Garcia JC, Blouin EF, et al. (2001b): Major surface protein la effects tick infection and transmission of Anaplasma marginale. Int J Parasitol, 31, 1705-1714.

15. De la Fuente J, Ruybal P, Mtshali MS, et al. (2007): Analysis of world strains of Anaplasma marginale using major surface protein la repeat sequences. Vet Microbiol, 119, 382-390.

16. Dumler JS, Choi K, Garcia-Garcia JC, et al. (2005): Human granulocytic anaplasmosis and Anaplasma phagocytophilum. Emerg Infect Dis, 11, 1828-1834.

17. Estrada-Peña A, Naranjo V, Acevedo-Whitehouse K, et al. (2009): Phylogeographic analysis reveals association of tick-borne pathogen, Anaplasma marginale, MSP1 $\alpha$ sequences with ecological traits affecting tick vector performance. BMC Biol, 57, 1-13.

18. Fedorina EA, Arkhipova AL, Kosovskiy GY, et al. (2019): Molecular survey and genetic characterization of Anaplasma marginale isolates in cattle from two regions of Russia. Ticks Tick Borne Dis, 10, 251-257.

19. Gokce HI, Genc O, Akca A, et al. (2008): Molecular and Serological Evidence of Anaplasma phagocytophilum Infection of Farm Animals in the Black Sea Region of Turkey. Acta Vet Hung, 56, 281-292.

20. Guo S, Yuan Z, Wu G, et al. (2002): Epidemiology of ovine theileriosis in Ganan region, Gansu Province, China. Parasitol Res, 88, 36-37.
21. Jongejan F, Uilenberg G (2004): The global importance of ticks. Parasitology, 129, 3-14.

22. Kocan KM, Blouin EF, Barbet AF (2000): Anaplasmosis Control. Past, Present, and Future. Ann N Y Acad Sci, 916, 501-509.

23. Lew AE, Bock RE, Minchin CM, et al. (2002): A mspla polymerase chain reaction assay for specific detection and differentiation of Anaplasma marginale isolates. Vet Microbiol, 86, 325-335.

24. Liu Q, Meli ML, Zhang Y, et al. (2016): Sequence heterogeneity in the 18S rRNA gene in Theileria equi from horses presented in Switzerland. Vet Parasitol, 221, 24-29.

25. Pipano E, Krigel Y, Frank M, et al. (1986): Frozen Anaplasma centrale vaccine against anaplasmosis in cattle. Br Vet J, 142, 553-556.

26. Schouls LM, Van De Pol I, Rijpkema SG, et al. (1999): Detection and identification of Ehrlichia, Borrelia burgdorferi sensu lato, and Bartonella species in Dutch Ixodes ricinus ticks. J Clin Microbiol, 37, 2215-2222.

27. Silva JB, Fonseca AH (2014): Risk factors for anaplasmosis in dairy cows during the peripartum. Trop Anim Health Prod, 46, 461-465.

28. Yang J, Han R, Liu Z, et al. (2017): Insight into the genetic diversity of Anaplasma marginale in cattle from ten provinces of China. Parasit Vectors, 10, 565.

29. Yin H, Liu G, Luo J, et al. (2003): Observation on the schizont stage of an unidentified Theileriasp. in experimentally infected sheep. Parasitol Res, 91, 34-39. 